\title{
Consumption of eelgrass (Zostera marina) by birds and invertebrates: an annual budget*
}

\author{
P. H. Nienhuis \& A. M. Groenendijk
}

Delta Institute for Hydrobiological Research, Vierstraat 28, 4401 EA Yerseke, The Netherlands

\begin{abstract}
During the period May 1978 to May 1979 living eelgrass in Lake Grevelingen, a marine lagoon in the SW Netherlands, provided quantifiable amounts of food to 9 species of macroconsumers, viz. 8 bird species (Cygnus olor, Anas penelope, A. platyrhynchos, A. acuta, A. crecca, Aythya ferina, Branta bernicla and Fulica atra) and 1 invertebrate, the isopod Idotea chelipes. From the eelgrass production of $35 \mathrm{~g} \mathrm{C} \mathrm{m}^{-2} \mathrm{yr}^{-1}, 1.05 \mathrm{~g} \mathrm{C} \mathrm{m}^{-2}$ was estimated to be ingested directly during the period May to September, $77 \%$ by $I$. chelipes and $23 \%$ by birds, mainly mute swan C. olor. From September to January $1.13 \mathrm{~g} \mathrm{C} \mathrm{m}^{-2}$ was consumed, mainly by migratory birds (68\%) and far less by $I$. chelipes $(32 \%)$. From January to May only $0.44 \mathrm{~g} \mathrm{C} \mathrm{m}^{-2}$ was consumed, mainly by birds $(66 \%)$. Overall consumption was estimated at $2.62 \mathrm{~g} \mathrm{C} \mathrm{m}^{-2} \mathrm{yr}^{-1}$, i.e. $7.5 \%$ of the Zostera marina annual production, $3.7 \%$ by birds and $3.8 \%$ by $I$. chelipes.
\end{abstract}

\section{INTRODUCTION}

Eelgrass Zostera marina L. occurs in temperate marine and brackish coastal waters throughout the northern hemisphere. Eelgrass beds are important to the overall productivity of the coastal zone. Annual net production of $Z$. marina averages 60 to $340 \mathrm{gC}$ $\mathrm{m}^{-2} \mathrm{yr}^{-1}$ in beds studied in various parts of the North Atlantic area (Mann 1972, Zieman \& Wetzel 1980).

Recent interest in marine plant-herbivore interactions is demonstrated in a number of reviews (Kikuchi \& Pérès 1977, Kikuchi 1980, Ogden 1980, Lubchenco \& Gaines 1981, Gaines \& Lubchenco 1982, Thayer et al. 1984). It is generally stated that in temperate latitudes few animal species use living Zostera spp. as a food source. It is further claimed that eelgrass yields only a small fraction of its production to grazing food chains and that the remainder enters detritus food chains. Quantitative evidence for these statements is poor, and only a few studies have attempted to assess spatial and temporal variability in herbivorous impact (cf. Nienhuis \& van Ierland 1978, Kikuchi 1980, Jacobs et al. 1981, Groenendijk 1984). Annual budgets are lacking in the literature.

The present study was carried out in Lake Grevelingen in the SW Netherlands, a former estuary and

- Communication no. 333 of the DIHO, Yerseke since 1971 a marine lagoon connected with the North Sea by sluices. The lagoon has a surface area of $108 \mathrm{~km}^{2}$ and about $60 \%$ of the area is shallower than $5 \mathrm{~m}$. Lake Grevelingen contains about $40 \mathrm{~km}^{2}$ of $Z o$ stera marina: the only significant population on the continental coast of Europe between northern France and Denmark. Eelgrass above-ground biomass is almost zero in winter. Development starts in May, reaches a peak in July and August and declines in September and afterwards (Nienhuis \& de Bree 1977 . 1980). Production of $Z$. marina in 1978 amounted to $107 \mathrm{~g} \mathrm{C} \mathrm{m}^{-2}$ in the seagrass beds, and $35 \mathrm{~g} \mathrm{C} \mathrm{m}^{-2} \mathrm{yr}^{-1}$ over the whole Lake Grevelingen.

This publication is part of a series on functional aspects of the eelgrass community in Lake Grevelingen (for an overview see Nienhuis [1983b] and Verhagen \& Nienhuis [1983]). The aim of this paper is to quantify the consumption of fresh Zostera marina by macroconsumers (birds and invertebrates) on an annual basis.

\section{MATERIAL AND METHODS}

Field work was carried out between September 1978 and March 1979 in 3 permanent sampling plots at 0.4 to $0.8 \mathrm{~m}$ water depth in a dense eelgrass bed near Herkingen in Lake Grevelingen. Quantitative sam- 
pling of the isopod Idotea chelipes and eelgrass was done approximately every 2 wk by pushing a $0.25 \mathrm{~m}^{2}$ steel cylinder of $0.9 \mathrm{~m}$ height a few centimeters into the sediment and subsequently collecting the eelgrass and connected epifauna with a bag net of $1.2 \mathrm{~mm}$ mesh size. The collected material was sorted and dried to constant weight at $80^{\circ} \mathrm{C}$.

In the quantitative consumption experiments, pieces of fresh eelgrass leaves (length 2 to $5 \mathrm{~cm}$ ) of a known surface area, carefully cleaned of epiphytes by rubbing, were placed into seawater-filled $150 \mathrm{ml}$ glass jars, together with a maximum of 5 Idotea chelipes individuals (length 2.5 to $8 \mathrm{~mm}$ ). These experiments were carried out in darkness to prevent regrowth of epiphytes, and had an average duration of $9 \mathrm{~d}$. The surface area of the remaining plant fragments was afterwards assessed. If only the epidermal layer of one side of the leaf was consumed, this surface area was divided by a factor of 3 (cf. Nienhuis \& van Ierland 1978). Seventeen experiments were performed at $18^{\circ} \mathrm{C}, 14$ at 9 to $10^{\circ} \mathrm{C}, 8$ at $4^{\circ} \mathrm{C}$, and 5 at $1^{\circ} \mathrm{C}$.

Consumption in $\mathrm{g} \mathrm{C} \mathrm{m}^{-2}$ in the sample plot was calculated by estimation of the consumption under experimental conditions in $\mathrm{g}$ DW per g DW of Idotea chelipes per day. Dry weight (DW) was converted to C by using a factor of 0.38 (Harrison \& Mann 1975). Using I. chelipes biomass and numbers of individuals, consumption could thus be calculated. Consumption data were divided by an arbitrary factor of 2 to reach actual consumption in the field. The choice of this factor is supported by evidence from field samples (Groenendijk 1984).

During the period July 1978 to July 1979 herbivorous birds in Lake Grevelingen were counted fortnightly by observers of the State Forestry Service (P. Maas unpubl.), from a boat or directly from the shore. It was assumed that the birds actually counted on the lake feed on eelgrass. The number of bird-days (BD) per 2 wk or per month were obtained by multiplying the bird numbers counted by the number of days during the period of observation. To determine consumption (C) the standard metabolism (M) in $\mathrm{kcal} \mathrm{d}^{-1}$ $\left(=4.187 \mathrm{~kJ} \mathrm{~d}^{-1}\right)$ was estimated according to the formula:

$$
\log M=\log 78.3+0.723 \log W
$$

where $\mathrm{W}=$ body weight in $\mathrm{kg}$ (Lasiewski \& Dawson 1967). Body weights were taken from Bauer \& Glutz von Blotzheim $(1968,1969)$ and from Glutz von Blotzheim et al. (1973). Kcal were converted to $\mathrm{g}$ DW by multiplying by 0.2 , and DW was converted to $\mathrm{C}$ by multiplying by 0.38 . To obtain consumption per bird the standard metabolism was multiplied by a factor 3 for net food assimilation and by a factor 1.67 for food assimilation efficiency (R. H. D. Lambeck unpubl.).
The fraction of eelgrass in the birds' menu (F) was roughly estimated from literature data (Bauer \& Glutz von Blotzheim 1968, 1969, Glutz von Blotzheim et al. 1973) and feeding behaviour observed in the field (Nienhuis \& van Ierland 1978) (Table 1). Consumption ( $\mathrm{g} \mathrm{C} \mathrm{m}^{-2}$ ) was then calculated as follows:

$$
\mathrm{C}=\frac{\left(78.3 \times \mathrm{W}^{0.723} \times 0.2 \times 3 \times 1.67 \times 0.38 \times \mathrm{F} \times \mathrm{BD}\right)}{108 \times 10^{6}}
$$

Table 1. Calculated consumption of eelgrass by herbivorous birds in Lake Grevelingen during the period July 1978 to July 1979. $\mathrm{F}=$ percentage of eelgrass in birds menu

\begin{tabular}{|lrc|}
\hline Bird species & $\mathrm{F}$ & $\begin{array}{c}\text { Eelgrass } \\
\text { consumption } \\
\mathrm{g} \mathrm{C} \mathrm{m}^{-2}\end{array}$ \\
\hline Anas platyrhynchos (mallard) & 25 & 0.124 \\
Anas penelope (wigeon) & 50 & 0.286 \\
Anas acuta (pintail) & 25 & 0.013 \\
Anas crecca (teal) & 25 & 0.029 \\
Aythya ferina (pochard) & 50 & 0.015 \\
Branta bernicla (brent goose) & 100 & 0.074 \\
Cygnus olor (mute swan) & 100 & 0.524 \\
Fulica atra (coot) & 50 & 0.241 \\
Total & & 1.306 \\
\hline
\end{tabular}

\section{RESULTS}

\section{Consumption by invertebrates}

Among the epifaunal macroinvertebrates associated with Zostera marina in Lake Grevelingen, the only one consuming significant amounts of eelgrass is the isopod Idotea chelipes (Nienhuis \& van Ierland 1978); we therefore concentrated our experiments on this species. During autumn and winter 1978-1979 the density of the $I$. chelipes population showed a decreasing trend from approximately 600 to 400 ind $\mathrm{m}^{-2}$, based on averaged monthly data (Fig. 1). During this period of observation a rapid decline of above-ground eelgrass biomass from a maximum of $32 \mathrm{~g} \mathrm{C} \mathrm{m}^{-2}$ occurred during September and October. The dead material was transported from the plots by wind and wave action. During winter the standing stock amounted to less than $5 \mathrm{~g} \mathrm{C} \mathrm{m}^{-2}$ (Fig. 1).

Field observations of Idotea chelipes showed active shredding and browsing on both green and brown eelgrass leaves. Many leaf edges in the seagrass beds showed shredding marks. In faecal pellets of $I$. chelipes sampled in autumn at the permanent field sites, 40 to $80 \%$ of particles larger than $1 \mathrm{~mm}$ contained recognizable eelgrass fragments.

In the laboratory experiments no difference was 


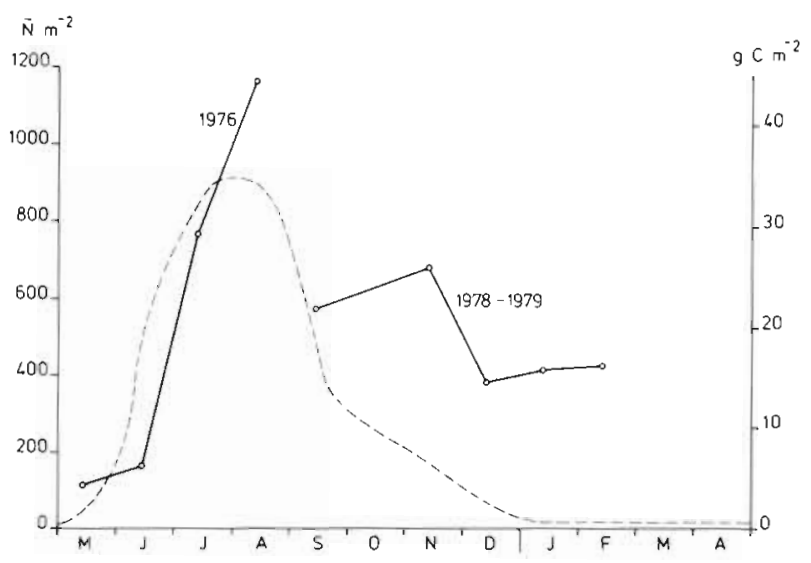

Fig. 1. Idoted chelipes. Numbers of individuals (o-o) in permanent sample plots in Lake Grevelingen eelgrass beds. Eelgrass biomass in $\mathrm{g} \mathrm{C}^{-2}(--)$ shown as a smoothed average annual curve over the period 1974 to 1978

observed between feeding time spent on brown or green leaves. Idotea chelipes spent at least $75 \%$ of its feeding time scraping the surface and shredding the edges of large leaf fragments, sometimes resulting in leaf breakage. The mean consumption rate at $18^{\circ} \mathrm{C}$ did not differ significantly from the rates at 9 to $10^{\circ} \mathrm{C}(0.042$ to $0.094 \mathrm{~g}$ DW eelgrass [g DW I. chelipes] ${ }^{-1} \mathrm{~d}^{-1}$ ) At $1^{\circ} \mathrm{C}$ consumption was zero. Differences in consumption rates between green and brown eelgrass, or in the presence or absence of additional mussel meat, were not significant. The total amount of eelgrass consumed over the period September 1978 to March 1979 was calculated at a maximum of $1.767 \mathrm{~g} \mathrm{C} \mathrm{m}^{-2}$ in eelgrass beds with a coverage of 70 to $90 \%$. Groenendijk (1984) gives full details on the results of the separate consumption experiments.

During summer $1978,44 \mathrm{~km}^{2}$ of eelgrass beds were mapped in Lake Grevelingen (Nienhuis 1980). A Spearman rank correlation between eelgrass cover and Idotea chelipes numbers spread over the entire Lake Grevelingen revealed a significant relation $(\mathrm{N}=33$, $r_{s}=0.729, p<0.001 ;$ Fortuin unpubl.). Under the assumptions that no consumption of eelgrass took place outside the eelgrass fields, and that actual consumption is $50 \%$ of consumption under experimental conditions, the integrated consumption of eelgrass over the entire Lake can be estimated at $(44 / 108 \times$ 1.767) $: 2=0.36 \mathrm{~g} \mathrm{C} \mathrm{m}^{-2}$.

\section{Consumption by birds}

Eight bird species in Lake Grevelingen should be considered as potential eelgrass consumers since they behave as facultative or obligate herbivores (Wolff et al. 1976) (Table 1). Every year large numbers of over- wintering or migrating waterfowl visit the lake. The numbers of herbivorous birds are given in Fig. 2 for the period July 1978 to July 1979. Numbers rose dramatically in late August and September to a maximum of 55,000 individuals, and decreased gradually to a minimum of 2,000 individuals in May. Counting data on the 2 most conspicuous eelgrass consumers are also given. Wigeons peaked in October to December (maximum 26,000 individuals) and showed very low numbers during the rest of the year. Mute swans occur in low numbers $(1,000$ to 2,000$)$ but are fairly constant over the year.

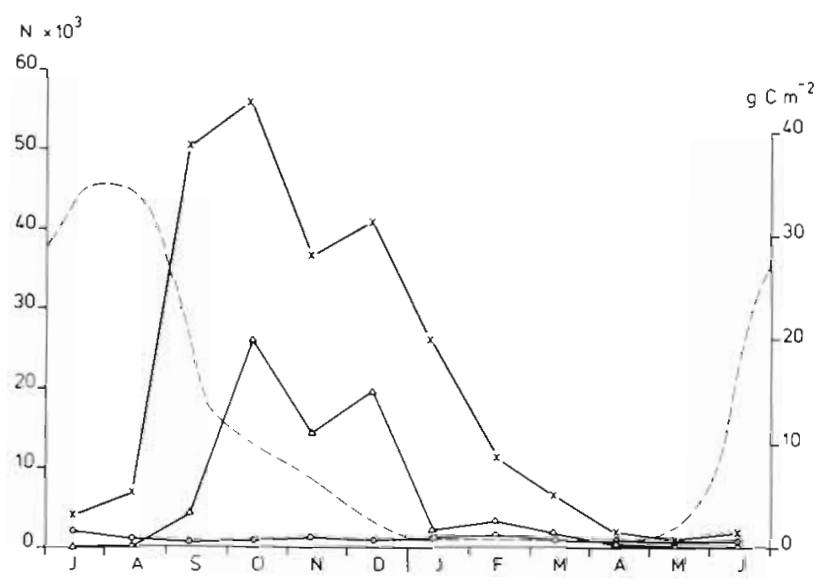

Fig. 2. Numbers of herbivorous birds $(x)$ counted in Lake Grevelingen over the period July 1978 to July 1979. Numbers of wigeon $(\Delta)$ and mute swan $(0)$ are also given. Eelgrass biomass (---) in $\mathrm{g} \mathrm{C} \mathrm{m}^{-2}$ shown as a smoothed average annual curve over the period 1974 to 1978

Calculated bird consumption values are given in Table 1, leading to an integrated value of $1.30 \mathrm{~g} \mathrm{C} \mathrm{m}^{-2}$ $\mathrm{yr}^{-1}$ over the entire Lake Grevelingen. A large part $(40 \%)$ is consumed by the mute swan, an obligate herbivore. Although present in low numbers, it consumes 7 to 20 times more per bird per day than geese and ducks. Wigeon took $22 \%$ of the total consumption assuming that only $50 \%$ of its diet consisted of eelgrass. Coot consumed $18 \%$, assuming that $50 \%$ of its food consisted of algae and perhaps (epi)benthic animals. The remainder of the bird population together consumed about $20 \%$. Among them is the brent goose, a known eelgrass feeder. Numbers of brent geese, appearing only in October and leaving the area in May, are comparatively low (max. 1,745 in November). Assuming a similar (very low) consumption in May and June 1978 to that in May and June 1979, consumption by birds can be partitioned as follows for the period May 1978 to May 1979: ingestion during May to August $0.24 \mathrm{~g} \mathrm{C} \mathrm{m}^{-2}$, during September to December $0.77 \mathrm{~g} \mathrm{C} \mathrm{m}^{-2}$ and during January to April $0.29 \mathrm{~g} \mathrm{C} \mathrm{m}^{-2}$. 


\section{DISCUSSION}

\section{Idotea chelipes}

One of the weaker assumptions in our budget is the translation of experimental results into actual field data. We assumed that Idotea chelipes consumed eelgrass at half estimated aquarium rates. Nevertheless, the removal of epibionts, which often show a high abundance especially on older leaves and are thought to be important in the diet of marine isopods (Carefoot 1973), may have caused an overestimation of consumption rates by $I$. chelipes. This species is potentially an omnivorous scavenger, although plant material always seems to provide the bulk of its food (Naylor 1955). One could suggest that $I$. chelipes responded in our experiments to a reduced preferential food supply. Abundant preferred food resources in the natural environment would preclude these animals from consuming macrophyte leaves directly.

Macrophytes contain compounds thought to deter grazing (e.g. phenolic-acids in Zostera marina [Harrison 1982] and in seaweeds [Steinberg 1984]). There is, however, accumulating recent evidence that isopods and amphipods consume fresh seagrass (Kirkman 1978, Nienhuis \& van Ierland 1978, Nicotri 1980, Robertson \& Mann 1980, Groenendijk 1984) and other living macrophytes (Strong \& Daborn 1979). The same is true for fresh-water isopods. Marcus et al. (1978) gave evidence that living leaves of Elodea canadensis are a very good food source for the isopod Asellus aquaticus in laboratory experiments, with supporting evidence that the living plant is consumed in the lake.

The great majority of evidence dealing with feeding behaviour of marine isopods and amphipods refers not to ingestion of living leaves but to the removal of surface fouling, either periphyton or detritus, from seagrass leaves (e.g. Harrison 1977, Zimmerman et al. 1979, Caine 1980, Howard 1982). Scraping or shredding of intact leaves may lead to initial fragmentation, and hence enhance decomposition processes. This may result in an interesting form of mutualism between grazers and seagrasses. Removal of surface fouling could lead to significantly increased rates of photosynthesis of the seagrass (Caine 1980, Howard 1982, Bulthuis \& Woelkerling 1983, Hootsmans \& Vermaat 1985).

Terrestrial isopods are efficient digesters but usually inefficient assimilators, whereas gastropods are both efficient digesters and assimilators (Wieser 1978). The same is presumably true for marine isopods and gastropods. Incorporated and attached bacteria and protozoa may be the most important food source for a marine isopod (Harrison \& Mann 1975, Fenchel 1977, Harrison 1977). The impact of Idotea chelipes on decomposition of eelgrass may therefore be mainly enhancement of fragmentation ( $75 \%$ of the eelgrass fragments in the faecal pellets are between 10 to $20 \mu \mathrm{m}$ ) and the subsequent increase in the rate of leaching and decay and availability of the material for filter and suspension feeders.

The obvious relation between eelgrass cover percentage and Idotea chelipes numbers and between eelgrass biomass and $I$. chelipes biomass (Nienhuis \& van Ierland 1978) suggests that $I$. chelipes has a preference for eelgrass. This is not necessarily only a food preference because food preferences may be influenced by non-nutritional factors. Nicotri (1980) found that $I$. baltica's possible susceptibility to fish predation and preference for moderate wave exposure may select for a primary response to macrophytes as a habitat, rather than as a food source.

Consumption by Idotea chelipes on an annual basis can be calculated assuming (1) that consumption in November-December 1978 had the same (low) value as in March-April 1979 under comparable water temperature conditions, and (2) that consumption of eelgrass leaves in g DW (g DW I. chelipes) ${ }^{-1} \mathrm{~d}^{-1}$ during the period May to August $1976\left(0.647 \mathrm{~g} \mathrm{C} \mathrm{m}^{-2}\right.$; Nienhuis \& Van Ierland 1978) is of the same order of magnitude as during the period May to August 1978 , taking into account the considerable increase of the surface area of the eelgrass beds (from $28 \mathrm{~km}^{2}$ in $1975-1976$ to $44 \mathrm{~km}^{2}$ in 1978; Nienhuis 1980). It was estimated that about $80 \%$ of the total area of $44 \mathrm{~km}^{2}$ of eelgrass fields (Nienhuis 1983b) had the same dense eelgrass cover as the sample plot, and that the remaining $20 \%$ had a negligible eelgrass cover. The positive relation between eelgrass coverage (biomass) and $I$. chelipes numbers was mentioned above. Based on these data we can calculate consumption of 44 / $28 \times 0.8 \times 0.647 \mathrm{gC} \mathrm{m}^{-2}=0.81 \mathrm{gC} \mathrm{m}^{-2}$ over the entire Lake Grevelingen for May to August.

Although Nienhuis \& van Ierland (1978) used larger animals in their experiments than we did, consumption reached the same level 10.03 to $0.07 \mathrm{~g}$ DW $[\mathrm{g}$ DW $I$. chelipes] $]^{-1} \mathrm{~d}^{-1}$ ). Fig. 1 shows the numbers of Idoted chelipes per $\mathrm{m}^{2}$ dense eelgrass bed in 1976 and 1978-1979; in both periods abundance was positively related to eelgrass biomass.

Consumption of Idotea chelipes on an arinual basis (1978-1979) over the entire Lake Grevelingen for May to August was estimated at $0.81 \mathrm{~g} \mathrm{C} \mathrm{m}^{-2}$, for September to December $0.36 \mathrm{~g} \mathrm{C} \mathrm{m}^{-2}$, and for January to April $0.15 \mathrm{~g} \mathrm{C} \mathrm{m}^{-2}$. Thus, we estimate that $I$. chelipes consumed a total of $1.32 \mathrm{~g} \mathrm{C} \mathrm{m}^{-2} \mathrm{yr}^{-1}$.

Eelgrass production in Lake Grevelingen in 1976 amounted to $274 \mathrm{~g} \mathrm{AFDW} \mathrm{m} \mathrm{gr}^{-2} \mathrm{yr}^{-1}$ in a permanent dense eelgrass sample plot (Verhagen \& Nienhuis 1983). Owing to the high year-to-year similarity of 
biomass dynamics in the sample plot (Nienhuis 1983a), we assumed that production in 1978 reached the same level viz. $107 \mathrm{~g} \mathrm{C} \mathrm{m}^{-2} \mathrm{yr}^{-1}$. Therefore, eelgrass production can be calculated for 1978 for entire Lake Grevelingen $35 / 108 \times 107=35 \mathrm{~g} \mathrm{C} \mathrm{m}^{-2} \mathrm{yr}^{-1}$.

Thus, the isopod consumed $3.8 \%$ of the annual eelgrass production. Nienhuis \& van Ierland (1978) calculated that Idotea chelipes consumed $2.8 \%$ of the living eelgrass production during the growing season 1976 (May to Aug), which means that only a minor part was consumed during the rest of that year (Sep to Apr).

\section{Herbivorous birds}

The calculations of consumption by birds at Lake Grevelingen are indirect estimates containing a number of assumptions used earlier by Nienhuis \& van Ierland (1978). There was a negative relation between the net eelgrass biomass decrease from mid-August to mid-October (drop from 40 to $10 \mathrm{~g} \mathrm{C} \mathrm{m}^{-2}$ ) and bird number increase (from 5,000 to 55,000) (Fig. 2). The eelgrass biomass decrease, however, can have been caused by bird consumption only to a minor extent since less than $1 \mathrm{~g} \mathrm{C} \mathrm{m}^{-2}$ was ingested by birds during those months. By far the largest part must have been caused by natural decomposition and transport from the eelgrass beds.

After the closure of Lake Grevelingen in 1971, eelgrass distribution, and consequently production, increased dramatically from $16 \mathrm{~km}^{2}$ in 1973 via $28 \mathrm{~km}^{2}$ in 1975 to $44 \mathrm{~km}^{2}$ in 1978 (Nienhuis 1980). Numbers of herbivorous birds showed the same increasing tendency after 1971 (P. Maas, unpubl.). One could postulate that the increasing numbers of birds reflect an increasing size of the food resource. However, the carrying capacity of the food source (eelgrass) is far larger than increasing bird numbers suggest. A possible explanation might be that waterfowl are traditional in their choice of migration routes and feeding grounds, and it takes perhaps many years to become familiar with improved ecological conditions, including food supply.

When the birds arrive in late August there is exploitable green eelgrass available in excess, presumably reflected by the steep increase in bird numbers from mid-August to mid-October. In November and December bird numbers are still substantial, but the permanently submerged low standing stock of eelgrass must be difficult to exploit, indicating another (terrestrial) food source for the overwintering population.

Consumption data related to eelgrass biomass data indicate that herbivorous birds cannot exploit a permanently submerged eelgrass population as effectively as an intertidal one. Geese consume $17 \%$ of the intertidal eelgrass standing stock in Izembek Lagoon, Alaska,
USA, with a mean tidal difference of $1 \mathrm{~m}$ (McRoy 1966). The population of brent geese on the intertidal coast of Essex (U.K.) has exceeded the levels which the existing Zostera noltii food stock can support (Charman 1977). This has resulted in exhaustion of food supply early in winter, followed by sequential movement of birds to less preferred food sources (Enteromorpha, salt marsh plants etc.). Tubbs \& Tubbs (1983) observed the same phenomenon in the Solent area (U.K.). After exhaustion of the intertidal Zostera beds (i.e. when leaf cover diminished below $10 \%$ ), herbivorous wildfowl (wigeon and brent geese) transferred to other food sources, such as green algae and permanent pastures. Jacobs et al. (1981) estimated that, within 3 mo (Sep to Dec 1974), birds consumed $26 \%$ of the annual production of $2 \mathrm{~g} \mathrm{C} \mathrm{m}^{-2} \mathrm{yr}^{-1}$ of intertidal Zostera noltij in the Dutch Wadden Sea. Brent geese took $19 \%$, pintail $31 \%$, wigeon $35 \%$ and mallard $15 \%$ of the $0.5 \mathrm{~g} \mathrm{C} \mathrm{m}^{-2}$ consumed. In absolute terms this integrated consumption is low, but it points to a highly efficient exploitation of the standing stock of $1 \mathrm{~g} \mathrm{C} \mathrm{m} \mathrm{m}^{-2}$ available.

Zostera spp. seem to be the preferred food of the brent geese while on their British wintering grounds (Charman 1977). Observations, however, do not always support the supposed food preference of brent geese. Ranwell \& Downing (1959) found at Scolt Head Island (U.K.) that Enteromorpha is their main food, and $Z$. noltii, although locally abundant, is not always eaten when the tides make it available. In Lake Grevelingen it is obvious that brent geese are not able to exploit their preferred food. They arrive in early October when $Z$. marina is strongly on the decline; eelgrass standing stock in winter is less than $5 \mathrm{~g} \mathrm{C} \mathrm{m}^{-2}$. Presumably more important is the fact that the sparse wintering population of $Z$. marina, consisting of small plants without flowering stems and growing deeper than $0.5 \mathrm{~m}$, are beyond the reach of the brent geese.

Nienhuis \& van Ierland (1978) estimated an eelgrass consumption by birds during the growing season May to September 1976 of $0.19 \mathrm{~g} \mathrm{C} \mathrm{m}^{-2}$ over entire Grevelingen. This figure matches fairly well with the consumption during the same period in $1978: 0.24 \mathrm{gC}$ $m^{-2}$.

\section{Annual budget}

We are now able to calculate an annual budget of production and consumption of eelgrass based on 1978-1979 data (Fig. 3). A production of $35 \mathrm{~g} \mathrm{C} \mathrm{m}^{-2}$ $\mathrm{yI}^{-1}$ is available. From May to September - the growing season $-1.05 \mathrm{~g} \mathrm{C} \mathrm{m}^{-2}$ of eelgrass was ingested directly, $77 \%$ by Idotea chelipes and $23 \%$ by birds, mainly mute swan. From September to January $1.13 \mathrm{~g} \mathrm{C} \mathrm{m}^{-2}$ was consumed, mainly by migratory birds 


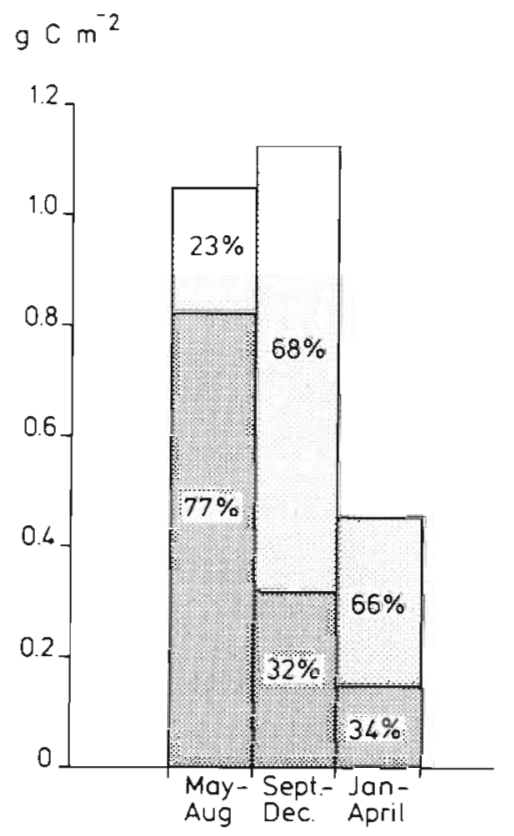

Fig. 3. Eelgrass consumption in 1978-1979 in Lake Grevelingen by birds (upper parts of bars) and Idotea chelipes (lower parts)

( $68 \%$ ) and far less by I. chelipes ( $32 \%)$. From January to May consumption reached a minimum of $0.44 \mathrm{~g} \mathrm{C}$ $\mathrm{m}^{-2}$. Bird impact $(66 \%)$ decreased strongly due to the difficult exploitation of the remaining eelgrass standing stock. Moreover, Lake Grevelingen was covered with ice for a few weeks during this period. An overall consumption value of $1.30+1.32 \mathrm{~g} \mathrm{C}^{2}=2.62 \mathrm{~g} \mathrm{C} \mathrm{m}^{-2}$ $\mathrm{yr}^{-1}$ is estimated i.e. $7.5 \%$ of the $35 \mathrm{~g} \mathrm{C} \mathrm{m}^{-2}$ available, $3.7 \%$ for birds and $3.8 \%$ for $I$. chelipes.

Based on work in Chesapeake Bay, Thayer et al. (1984) estimated that bird consumption accounts for about $3 \%$ of the annual areal eelgrass production of above-ground leaf material.

Acknowledgements. Dr. E. K. Duursma and Dr. R. H. D. Lambeck (DIHO, Yerseke) critically read the manuscript.

\section{LITERATURE CITED}

Bauer, K. M., Glutz von Blotzheim, U. N. (1968). Handbuch der Vögel Mitteleuropas 2. Akadem. Verlagsgesellschaft, Frankfurt am Main

Bauer, K. M., Glutz von Blotzheim, U. N. (1969). Handbuch der Vögel Mitteleuropas 3. Akadem. Verlagsgesellschaft, Frankfurt am Main

Bulthuis, D. A., Woelkerling, W. J. (1983). Biomass accumulation and shading effects of epiphytes on leaves of the seagrass, Heterozostera tasmanica, in Victoria, Australia. Aquat. Bot. 16: $137-148$

Caine, E. A. (1980). Ecology of two littoral species of Caprellid Amphipods (Crustacea) from Washington, USA. Mar. Biol. 56: $327-335$
Carefoot, T. H. (1973). Feeding, food preference and the uptake of food energy by the supralittoral isopod Ligia pallassii. Mar. Biol. 18: 228-236

Charman, K. (1977). The grazing of Zostera by wildfowl in Britain. Aquaculture 12: 229-233

Fenchel, T. M. (1977). Aspects of decomposition of seagrasses. In: McRoy, C. P., Helfferich, C. (ed.) Seagrass ecosystems. A scientific perspective. Dekker, New York, p. 123-145

Gaines, S. D., Lubchenco, J. (1982). A unified approach to marine plant-herbivore interactions. II. Biogeography. Ann. Rev. Ecol. Syst. 13: 111-138

Glutz von Blotzheim, U. N., Bauer, K. M., Bezzel, E. (1973). Handbuch der Vögel Mitteleuropas 5. Akadem. Verlagsgesellschaft, Frankfurt am Main

Groenendijk, A. M. (1984). Consumption of eelgrass (Zostera marina L.) by the isopod Idotea chelipes (Pallas) in Lake Grevelingen, after the growing season. Neth. J. Sea Res. 18: 384-394

Harrison, P. G. (1977). Decomposition of macrophyte detritus in seawater: effects of grazing by amphipods. Oikos 28 : 165-169

Harrison, P. G. (1982). Control of microbial growth and of amphipod grazing by water-soluble compounds from leaves of Zostera marina. Mar. Biol. 67: 225-230

Harrison, P. G., Mann, K. H. (1975). Chemical changes during the seasonal cycle of growth and decay in eelgrass (Zostera marina) on the Atlantic coast of Canada. J. Fish. Res. Bd Can. 32: 615-621

Hootsmans, M. J. M., Vermaat, J. E. (1985). The effect of periphyton grazing by three epifaunal species on the growth of Zostera marina L. under experimental conditions. Aquat. Bot. 22: 83-88

Howard, R. K. (1982). Impact of feeding activities of epibenthic amphipods on surface-fouling of eelgrass leaves. Aquat. Bot. 14: 91-97

Jacobs, R. P. W. M., den Hartog, C., Braster, B. F., Carriere, F. C. (1981). Grazing of the seagrass Zostera noltii by birds at Terschelling (Dutch Waddensea). Aquat. Bot. 10: 241-259

Kikuchi, T. (1980). Faunal relationships in temperate seagrass beds. In: Phillips, R. C., McRoy, C. P. (ed.) Handbook of seagrass biology: an ecosystem perspective. Garland STPM Press, New York, p. 153-172

Kikuchi, T., Pérès, J. M. (1977). Consumer ecology of seagrass beds. In: McRoy, C. P., Helfferich, C. (ed.) Seagrass ecosystems. A scientific perspective. Dekker, New York, p. $147-193$

Kirkman, H. (1978). Growing Zostera capricorni Aschers in tanks. Aquat. Bot. 4: 367-372

Lasiewski, R. C., Dawson, W. R. (1967). A re-examination of the relation between standard metabolic rate and body weight in birds. Condor 69: 13-23

Lubchenco, J., Gaines, S. D. (1981). A unified approach to marine plant-herbivore interactions. I. Populations and communities. Ann. Rev. Ecol. Syst. 12: 405-437

Mann, K. H. (1972). Macrophyte production and detritus food chains in coastal waters. Memorie Ist. Ital. Idrobiol. 29 (Suppl.): 353-383

Marcus, J. H., Sutcliffe, D. W., Willoughby, L. G. (1978) Feeding and growth of Asellus aquaticus (Isopoda) on food items from the littoral of Windermere, including green leaves of Elodea canadensis. Freshwat. Biol. 8: 505-519

McRoy, C. P. (1966). The standing stock and ecology of eelgrass (Zostera marina L.) in Izembek Lagoon, Alaska. M.S. thesis, Univ. Washington (Univ. Microfilms, Ann Arbor, Michigan M-2144) 
Naylor, E. (1955). The diet and feeding mechanism of Idotea. J. mar. biol. Ass. U.K. 34: 347-355

Nicotri, M. E. (1980). Factors involved in herbivore food preference. J. exp. mar. Biol. Ecol. 42: 13-26

Nienhuis, P. H. (1980). The eelgrass (Zostera marina L.) subsystem in brackish Lake Grevelingen: production and decomposition of organic matter. Ophelia, Suppl, 1: $113-116$

Nienhuis, P. H. (1983a). Zeegrasgemeenschap in het Grevelingenmeer. In: Parma, S., van Emden, $\mathrm{H}$. M. et al. (ed.) Oecologie van meren en plassen. Pudoc, Wageningen, p. $36-56$

Nienhuis, P. H. (1983b). Temporal and spatial patterns of eelgrass (Zostera marina L.) in a former estuary in The Netherlands, dominated by human activities. J. mas. Technol. Soc. 17 (2): 69-77

Nienhuis, P. H., de Bree, B. H. H. (1977). Production and ecology of eelgrass (Zostera marina L.) in the Grevelingen estuary, The Netherlands, before and after the closure. Hydrobiologia 52: 55-66

Nienhuis, P. H., de Bree, B. H. H. (1980). Production and growth dynamics of eelgrass (Zostera marina) in brackish Lake Grevelingen (The Netherlands). Neth. J. Sea Res. 14: $102-118$

Nienhuis, P. H., van lerland, E. T. (1978). Consumption of eelgrass, Zostera marina, by birds and invertebrates during the growing season in Lake Grevelingen (SW Netherlands). Neth. J. Sea Res. 12: 180-194

Ogden, J. C. (1980). Faunal relationships in Caribbean Seagrass beds. In: Phillips, R. C., McRoy, C. P. (ed.) Handbook of seagrass biology: an ecosystem perspective. Garland STPM Press, New York, p. 173-198

Ranwell, D. S., Downing, B. M. (1959). Brent goose (Branta bernicla [L.]) winter feeding pattern and Zostera resources at Scolt Head Island, Norfolk. Anim. Behav. 12: 42-56
Robertson, A. I., Mann, K. H. (1980). The role of isopods and amphipods in the initial fragmentation of eelgrass detritus in Nova Scotia, Canada. Mar. Biol. 59: 63-69

Steinberg, P. D. (1984). Algal chemical defence against herbivores: allocation of phenolic compounds in the kelp Alaria marginata. Science 223: 405-407

Strong, K. W., Daborn, G. R. (1979). Growth and energy utilisation of the intertidal isopod Idotea baltica (Pallas) (Crustacea: Isopoda). J. exp. mar. Biol. Ecol. 41: 101-123

Thayer, G. W., Bjorndal, K. A., Ogden, J. C., Williams, S. L., Zieman, J. C. (1984). Role of larger herbivores in seagrass communities. Estuaries 7: 351-376

Tubbs, C. R., Tubbs, J. M. (1983). The distribution of Zostera and its exploitation by wildfowl in the Solent, Southern England. Aquat. Bot. 15: 223-239

Verhagen, J. H. G., Nienhuis, P. H. (1983). A simulation model of production, seasonal changes in biomass and distribution of eelgrass (Zostera marina) in Lake Grevelingen. Mar. Ecol. Prog. Ser. 10: 187-195

Wieser, W. (1978). Consumer strategies of terrestrial gastropods and isopods. Oecologia (Berl.) 36: 191-201

Wolff, W. J., van Haperen, A. M. M., Sandee, A. J. J., Baptist, H. J. M., Saeijs, H. L. F. (1976). The trophic role of birds in the Grevelingen estuary, The Netherlands, as compared to their role in the saline Lake Grevelingen. In: Persoone, G., Jaspers, E. (ed.) Proc. 10th Europ. Mar. Biol. Symp., Ostend, Belgium, Vol, 2. Universa Press, Wetteren, p. $673-689$

Zieman, J. C., Wetzel, R. G. (1980). Productivity in seagrasses: methods and rates. In: Phillips, R. C., McRoy, C. P. (ed.) Handbook of seagrass biology: an ecosystem perspective. Garland STPM Press, New York, p. 87-116

Zimmerman, R., Gibson, R., Harrington, J. (1979). Herbivory and detritivory among Gammaridean Amphipods from a Florida seagrass community. Mar. Biol. 54: 41-47

This paper was presented by Dr. J. J. Zijlstra; it was accepted for printing on November 8, 1985 